\title{
A DIGITALIZÁCIÓ SZEREPE ÉS JELENTŐSÉGE A MODERN MEZŐGAZDASÁGI VÁLLALKOZÁSOKNÁL EGY KUTATÁS TÜKRÉBEN
}

\author{
Berta Olga
}

\begin{abstract}
Absztrakt: Az digitalizáció egyre nagyobb érdeklödésre tart számot a mezőgazdasági szereplök körében, amelyek segítségével hatékonyabb mezögazdasági müködés, illetve fejlesztés valósítható meg. Az informatikai alkalmazások és a mezőgazdaság viszonya felfedezhetö a termelési technológiák összehangolásában, a mezögazdaság, vagy az ennél tágabb értelmezést jelentö agribusiness árutermelési és piaci igazgatása, valamint a fejlesztések közötti kapcsolat egyértelmüen rajzolódik ki. A mezögazdasággal kapcsolatos információk, mint például az inputok, piacok, ár, infrastruktúra, technológiai változások informatikai ismerete alapvető eszköze lett a mezőgazdasági fejlesztéseknek. Ebbe a folyamatba szerversen integrálódik a precíziós mezőgazdaság, mely, mint a neve is mutatja a mezőgazdasági eszközök müködtetésében rejlö tartalékok kihasználásán, a precízebb eszközhasználaton alapul. Az elmúlt időszakban kezdtek elterjedni a rendszer egyes részei hazánkban is szélesebb körben. A tulajdonos számára széleskörü információt szolgáltat a munkavégzési folyamatokról, amit fel tud használni a későbbi döntéshozatalnál, így a menedzsment munkáját is könnyíti, illetve jelentősen befolyásolja. Kutatásom során egy kérdőív segítségével igyekeztem feltérképezni a hazai agrárvállalkozások vezetöit és informatikához való viszonyukat, attitüdjüket. Arra kerestem a választ, mely tényezők befolyásolják az agrárszervezeteket az információs rendszerek, precíziós eszközök használatában.
\end{abstract}

Abstract: There is an ever-growing interest in digitization among the actors of the agrarian sector, with the help of which a more efficient agrarian operation and development may be implemented. The relationship of IT applications and agriculture is present in the harmonization of production technologies, or in the relationship between developments and agriculture, more broadly, the production and market management of agribusiness. Information pertaining to agriculture, such as inputs, markets, prices, infrastructure, the IT background of technological changes have become basic tools of agrarian development. Precision agriculture, which, as its name demonstrates, is based on the exploitation of reserves in agricultural equipment and precise use of tools, is organically integrated into this process. The individual elements of the system began to spread in Hungary in the recent period. It provides a broad spectrum of information about the production process for the owner that they can use for later decision making, thus it facilitates and considerably affects the work of the management. In my research, I aimed at mapping the managers of Hungarian agrarian enterprises and their relationships and attitudes to IT systems. I was attempting to answer the question of the factors that influence agrarian organisations in the use of information and precision systems.

Kulcsszavak: agrárium, precíziós mezögazdaság, reprezentatív, kutatás

Keywords: agribusiness, precision agriculture, representative, survey

\section{Bevezetés}

A gazdaságban az információs rendszerek használata az elmúlt években gyors növekedésnek indult, amely annak köszönhetö, hogy a vezetők üzleti döntéseik meghozatalakor egyre gyakrabban használják ezeket a rendszereket a hatékonyabb gazdálkodás érdekében. Azonban az információs technológia rohamosan változik, és ezzel együtt szaporodtak azok a problémák is, amelyekkel a döntéshozóknak szembe kell nézniük. 
Az információs technológia segítségével hatékonyabb mezőgazdasági müködés. illetve fejlesztés valósítható meg. A termelési és termesztési technológiák összehangolása, a mezőgazdaság, vagy az ennél tágabb értelmezést jelentó agrárágazat árutermelési és piaci igazgatása, valamint a fejlesztések közötti kapcsolat egyértelmü. Így a mezőgazdasággal kapcsolatos információk, mint például az inputok, piacok, ár, infrastruktúra, technológiai változások informatikai ismerete alapvetö eszköze lett a mezögazdasági fejlesztéseknek.

Az agrárium fejlödése tehát, hasonlóan a többi ágazathoz, nagymértékben függ az információk hozzáférésétől. Az információk segítségével számos más cél, a profit maximalizálása, vagy például a környezeti hatások csökkentése is megvalósítható.

Kutatásom során számos, az agráriumot jelentősen megreformáló és befolyásoló fejlesztéssel találkoztam. A kutatók is szerteágazóan foglalkoznak a szakterülettel. így az Új-Mexikói Egyetem agrárökonómia professzora L. Catlett (2013), az agrárium utóbbi évtizedét öt döntỏen befolyásoló technológiai újításra osztotta fel:

- GPS, a globális helymeghatározó rendszer, mely a precíziós mezőgazdaság kialakulásához vezetett;

- biotechnológia fejlődése (GMO terjedése),

- internet jelentőségének növekedése,

- müholdas időjárás elörejelzés pontosságának javulása,

- mobiltelefonok (távközlés és információ technológia) ugrásszerü fejlődése.

A jövőkutatók folyamatosan vizsgálják a mezőgazdaságban még rejlő lehetőségeket, keresik az alternatívákat, miközben szemmel kell tartanunk a fenntartható fejlődés elveinek való megfelelést is. Catlett ebben is nagy fejlödési potenciált lát a következő évtizedben. Kiemeli a technológiai fejlesztések közül a vezeték nélküli digitális technológiák (Wi-Fi, Bluetooth), a nanotechnológia és DNS érzékelö chipek, a biotechnológia és az intelligens informatikai rendszerek alkalmazását, fejlesztését.

Ugyanakkor Jóri (2017) már a digitális mezőgazdasági 4.0 kialakulását is elemzi írásában, és kiemeli az olcsó és fejlett szenzorok, a felhő alapú IKT rendszerek, a mikroprocesszorok, a big data-analitikák, a szélessávú hálózati kommunikáció rohamos fejlődését. Kitér az eszközök internetének (IoT) dinamikus fejlödésére, a fedélzeti számítógépek és a szenzorok térnyerésére a termelési mủveletek során, a jármüvek kommunikációs „képességére” és a különböző automatizálási lehetöségekre, mint a permetezés, a kormányzás vagy a célzott helyre vetés területére. Az okos mezőgazdaság (smart farming) az első lépés a mezőgazdaság 5.0, vagyis a robotika felé az agráriumban is.

\subsection{A preciziós mezőgazdaságtól az okos farmig}

Számos cikk és konferencia foglalkozik a magyar agrárium lehetőségeivel, jövőjével, ugyanakkor a géppark elöregedése, a humán erőforrás alacsony képzettségének problémája is gyakran felmerül a viták során. Popp (2013) is kiemelte, hogy mai "agrármúzeum" nem tud ennyi embert eltartani a mezőgazdaságban. A jövő mezőgazdaságának alapja Popp szerint az új erőforrások hatékony alkalmazása, a tudásintenzív mezögazdasági technológiák használata, az 
energiatakarékos talajművelés, a folyamatos oktatás és képzés. Korábban már Györffy (1999) - aki az elsők között foglalkozott itthon a precíziós agrárgazdasággal - megfogalmazta: a világ mezőgazdasága válságban van. Ez a válság pedig kétoldalú: egyrészt a föld nagyobb részén a kis termésátlagok miatt százmilliók éheznek, másrészt oldalon a fejlett világban a túltermelés okoz gondokat. Ezek kiegészülnek az ökonómia és az ökológia ellentmondásával. A szerzö így az ipari mezőgazdaság alternatívájaként létrejött bio- vagy szervesgazdálkodás szélsőségeinek a mérsékeléséböl kialakuló az ún. mid-tech farming, vagyis a középutas gazdálkodásban látja a megoldást. Ezek alapján fogalmazta meg a precíziós gazdálkodás alaptételeit Györffy, ami magába foglalja a termöhelyhez alkalmazkodó termesztést, a táblán belül változó technológiát, a legújabb „csúcstechnológiákat”, az integrált növényvédelmet, távérzékelést, térinformatikát, geostatisztikai feltételrendszert, a növénytermesztés gépesítését, az információs technológiai fejlesztések megjelenését a növénytermesztésben.

\section{Anyag és módszer}

Vizsgálatomban egyszerü, véletlen mintavételi eljárást alkalmazva kérdeztem meg a kettős könyvvezetésü mezőgazdasági vállalkozásokat, kérdőíves felmérés segítségével. A minta kialakításánál fỏ motiváló tényező az volt, hogy „egyszerü véletlen mintavételt használunk homogén, véges elemszámú sokaság esetén, amikor a mintát visszatevés nélkül választjuk ki, minden lehetséges „n” elemü minta kiválasztásának azonos valószínüséget biztosítva”, ami a reprezentativitás előfeltétele (Hunyadi-Vita, 2008). A mintavétel során csak kettős könyvvezetésü vállalkozásokat vizsgáltam meg. A mintavételhez szükséges adatbázis összeállítása során az AKI-nál (Agrárgazdasági Kutató Intézet) sikerült egy olyan statisztikai adatsort találnom, mely a regisztrált mezőgazdasági vállalkozásokat tartalmazta, megyei szintre lebontva és fötevékenységenként összesítve a vállalkozásokat. Tölük megkapott lista lett az alapsokaságot biztosító adatbázisom.

A felmérésem alapjául szolgáló adatsor az AKI 2010. évi összesítése alapján készuilt, a lejegyzett kettős könyvvezetésü vállalkozásainak jegyzéke biztosította, amiben 10648 mezőgazdasági vállalkozás szerepel. Azért ezt választottam, mert így rendelkezésemre állt egy olyan adatbázis, melyben szerepeltek a mezőgazdasági vállalkozások legfontosabb adatai: szervezet neve, címe, telefonszáma, fötevékenységi kódok, valamint éves nettó árbevétele.

A kutatás fő vázát egy kérdőives megkérdezés adta. Ahogy a szakirodalomban Babbie (2008) megfogalmazza, egy felmérés egy bizonyos népesség jellemzőit egy adott populációból vett minta összegyüjtésével és a statisztikai módszertan felmérésével értékeli. A kérdőiv vagy egy felmérés kérdéseinek feltevése a válaszadók adott információinak kiszürésére szolgál. Négy alapvetö célja van: először összegyüjti a megfelelő adatokat, másodszor biztosítja az adatok összehasonlíthatóvá tételét és az elemzésre való alkalmasságot, harmadszor minimalizálja a félreértést a kérdés megfogalmazásában és feltárásában, végül kérdéseket tesz fel és változtat Brace szerint (2008). 
A kérdőívem összeállítása során segítséget jelentett egy elözetes, félig strukturált mélyinterjú keretében végzett vizsgálat, amikor felmértem 10 különböző méretü mezögazdasági vállalkozásnál, hogy milyen föbb kérdésekre érdemes koncentrálnom a téma keretei között. Ackroyd és Huges (1992) szerint az interjú egy olyan, a kutató és a válaszadó közötti létrejövő találkozás, amelyben utóbbi a kutatott téma szempontjából fontos (releváns) kérdések sorozatát teszi fel. A válaszadó válaszai pedig a nyersanyagot képezik, amelyet egy későbbi időpontban elemeznek. A mélyinterjú egy négyszemközt készülő eljárás, amelynek célja, hogy felmérje a fogyasztó legmélyebb motivációit és a tudattalan indítékait megismerje. (Malhotra, 2005) Ezek az interjúk lehetnek strukturált, strukturálatlan és félig strukturált mélyinterjúk. Ahogy Kárpáti-Lehota (2010) megfogalmazta, a félig strukturált interjú egyik elönye, hogy egyaránt könnyen alkalmazható kvalitatív és kvantitatív szemléletú piackutatásban. A strukturált és a nem strukturált kérdések kombinációjával nagy mennyiségü adattal fedhetjuik le az adott piackutatási témakört. A rugalmas kérdésekkel és a vizsgálandó témakörök fókuszban tartásával mély és összetett adatsorokhoz juthatunk.

A mélyinterjú egyik legismertebb válfaja a célinterjú. A célzott interjúk készitése során egy adott probléma, jelenség áll a kérdező érdeklődésének középpontjában, nem pedig az interjúalany személyisége. Ezen interjúk célja az adoti témával kapcsolatos tények, vélemények összegyüjtése, adekvát információk beszerzése. Az interjú körülményei hasonlítanak a mélyinterjúhoz, de a célzott interjú, mint a neve is mutatja, jobban strukturált és csupán szakmai kérdésekre, problémakörre koncentrál. A tapasztalat azt mutatja, hogy a célzott interjúk hatékonyan egészítik ki az empirikus adatfelvételi módszereket, mivel készítésük során a hangsúlyt azokra a problémákra, kérdésekre helyezik, melyeket nem, vagy csak áttételesen lehet vizsgálni más eszközökkel (Tóth-Káposzta, 2013).

Ezek alapján a célinterjú készítés tünt a legmegfelelőbb módszernek, annak érdekében, hogy a legpontosabb és legalaposabb felmérést tudjam elözetesen elvégezni, ami alapján össze tudom állítani a kérdőivet a kutatás teljes lefolytatásához.

\section{Eredmények és értékelésük}

3.1. A számítógépes rendszerére, az információgazdálkodásra vonatkozó általános kérdések eredményei

Kutatásom szerint az internetet használó agrárvállalkozások esetében a számítógépet használó vállalkozók több, mint 10 százaléka jelezte, hogy nem használja az internetet, míg 89,6 százalék folyamatos, heti és havi rendszerességú használatot jelzett. A munkatársak internet használatára vonatkozó adatok hasonlóan alakulnak: a számítógépet használó alkalmazottak $21,8 \%$ nem használja, 78,2\% azonban folyamatosan használja munkájában az internetet. Némileg árnyalta a képet, amikor a tervekre kérdeztem rá. Ebben az esetben azok a vállalkozások, amelyek nem használnak számítógépet mindössze 15,6 százalékban jelezték, hogy egy éven belül bevezetnék a számítógéphasználatot. Az internethasználat esetében kissé rosszabb 
az arány, itt mindössze $11,1 \%$ mondta, hogy bevezeti az internetet a rendszeres munkafolyamatba. Viszont a nemlegesen válaszolók aránya mindkét kérdés esetében 80 százalék fölötti, ami a mai, interneten és informatikai eszközökön alapuló és rohamosan fejlődő gazdasági helyzetben nem érthető döntés.

Arra a kérdésre, hogy rendelkezik-e a vállalkozás honlappal, mindössze 28,51 százalék válaszolta, hogy van honlapja. Sajnos azonban a honlappal nem rendelkezők 83,6 \%-ban jelezték, hogy nem is áll szándékukban honlapot üzemeltetni, az interneten a vállalkozásukkal megjelenni. Több okot soroltak fel ezzel kapcsolatban: drága; nem érzik eléggé hatékonynak; valós üzleti lehetőséget nem látnak benne; a meglévő üzletfelek tudnak róluk, és szájról szájra terjed a híre, hogy csak a legjellemzőbbeket említsem. A kérdőívben megkérdeztem a honlappal rendelkező vállalkozásokat, hogy milyen szolgáltatásokat biztosítanak a webes felületükön, melynek válaszait az 1. ábra mutatja.

\section{1. ábra: Honlappal rendelkező vállalkozások által nyújtott szolgáltatások megoszlása}

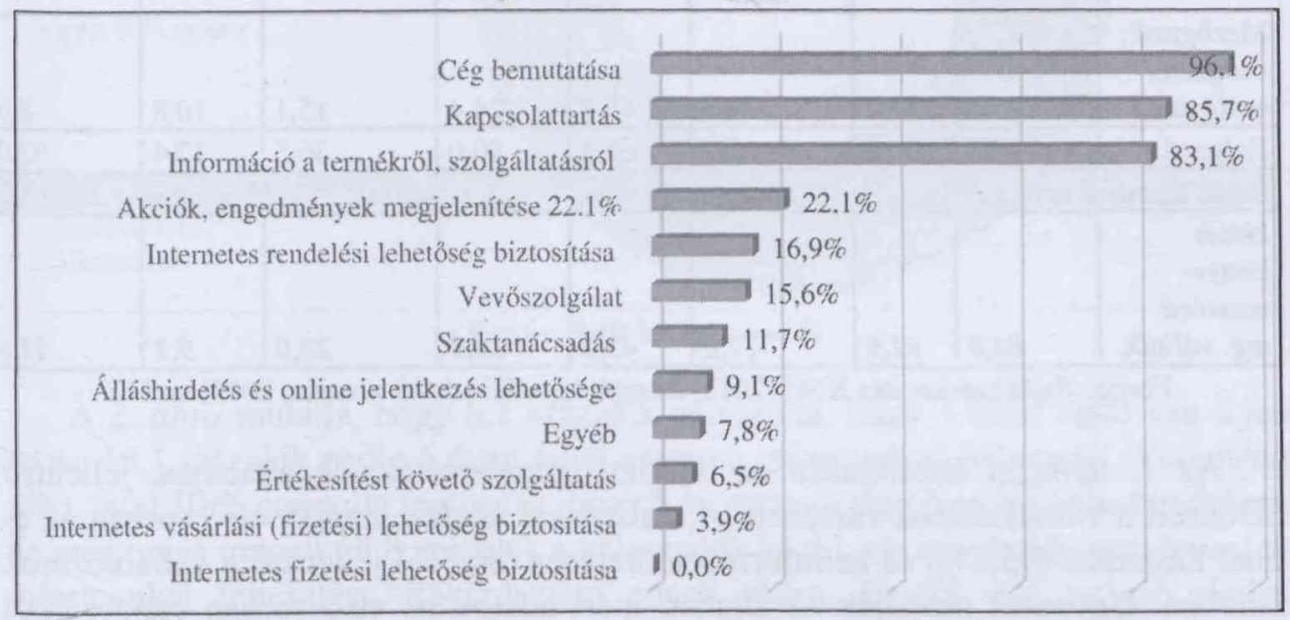

Forrás: Saját kutatás; $\mathrm{n}=77$

$\mathrm{Az}$ ábra mutatja, hogy a honlappal rendelkező vállalkozások milyen szolgáltatásokat tesznek elérhetővé. Eszerint a cég bemutatását 96,1\%-ban, a kapcsolattartási lehetőséget $85,7 \%$ esetében biztosították. Információt a termékről, szolgáltatásról $83,1 \%$ adott, és $9,1 \%$-ban adott a honlap online lehetőséget álláshirdetésre. Vevőszolgálat online biztosítása $15,6 \%$ esetében, míg az akciók, engedmények megjelenítése $22,1 \%$-nál volt. Szaktanácsadást $11,7 \%$, internetes rendelési lehetőséget $16,9 \%$ biztosított a világhálón. Internetes vásárlási lehetőséget $3,9 \%$ nyújtott, de az internetes fizetési lehetőség biztosítására senki sem válaszolt igennel. Az értékesítést követő szolgáltatás 6,5\%-a honlapon volt elérhető és egyéb szolgáltatást 7,8\% nyújtott. Az ábrán is látható a hatalmas szakadék: míg az alapfunkciók, mint a cég bemutatása, kapcsolattartás vagy a termékinformáció $80 \%$ feletti mértékben van jelen a honlapokon, addig a többi szolgáltatás már 30\% alatti mértékben jelenik meg. Ez azt eredményezi, hogy az internetet mindössze „szórólap” 
funkcióként alkalmazzák a vállalkozások, az interaktivitást és a digitális lehetőségeket nem aknázzák ki megfelelően.

$\mathrm{Az}$ 1. táblázat tartalmazza a $\mathrm{KSH}$ adatait, melyben a vállalkozások és a háztartások IKT eszközökkel való ellátottságát és ezek használatát vizsgálta. A kimutatás hasonló adatsorokat vetett össze, mint a kutatásom. Ez alapján már lehetett összehasonlítást is végeznem az eredményekkel. Valójában az adatok nem teljesen összevethetőek, mivel én a mikrovállalkozásokat is vizsgálom és megkérdeztem, míg a KSH adatsorában csak a 10 fönél több alkalmazottat foglalkoztató vállalkozások kerültek bele az alapsokaságba, ezáltal a mintába is.

\section{1. táblázat: Az internet igénybevételének százalékos megoszlása a mezőgazdaságban a 10 főnél többet foglalkoztató vállalkozásoknál}

\begin{tabular}{|l|r|r|r|r|r|r|r|r}
\hline $\begin{array}{c}\text { Nemzetgaz- } \\
\text { dasági ág }\end{array}$ & $\begin{array}{c}\text { Informá- } \\
\text { kió } \\
\text { keresése }\end{array}$ & $\begin{array}{c}\text { E- } \\
\text { mail }\end{array}$ & $\begin{array}{c}\text { Banki és } \\
\text { pénzügyi } \\
\text { szolg. } \\
\text { igénybevé } \\
\text {-tele }\end{array}$ & $\begin{array}{c}\text { Piacfi- } \\
\text { gyelés } \\
\text { (moni- } \\
\text { toring) }\end{array}$ & $\begin{array}{c}\text { Hirde- } \\
\text { tés/mar- } \\
\text { keting }\end{array}$ & $\begin{array}{c}\text { Termékek } \\
\text { és szolg. } \\
\text { vásárlása, } \\
\text { értékesítése }\end{array}$ & $\begin{array}{c}\text { Oktatás } \\
\text { I } \\
\text { képzés }\end{array}$ & $\begin{array}{c}\text { Értékesí- } \\
\text { tés utáni } \\
\text { szolg. való } \\
\text { hozzáférés }\end{array}$ \\
\hline $\begin{array}{l}\text { Mezögazd., } \\
\text { vadgazd., } \\
\text { erdögazd. }\end{array}$ & 86,5 & 95,7 & 71,3 & 43,8 & 24,4 & 15,1 & 10,8 & 8,6 \\
\hline Halgazd. & 91,3 & 100,0 & 81,7 & 65,2 & 80,0 & 36,5 & 17,4 & 33,0 \\
\hline
\end{tabular}

Saját kutatási eredmények kettős könyvvezetésü mg. vállalk. \begin{tabular}{l|l}
84,0 & 97,9
\end{tabular} \begin{tabular}{l|r|r|}
77,0 & 43,2 & 30,9 \\
\hline
\end{tabular} 23,0 9,1

Forrás: Saját szerkesztés KSH (2012) és saját kutatási adatok alapján; 2015; n=270

Az 1. táblázat tartalmazza az internet igénybevételének általános, jellemzơ kérdéseit a vállalkozások esetében. A statisztikai adatok alapján első sorban az e mail használat $(95,7 \%)$ és az információ keresés $(86,5 \%)$ jellemző a vállalkozások körében. Ugyanezt mutatják az általam mért adatok is: első sorban elektronikus levelezésre $(97,9 \%)$ és 84 százalékban általános információ keresésére használják az internetet az agrárvállalkozások napjainkban Magyarországon. A legkevésbé jellemző a képzés és a termék, szolgáltatás értékesítés utáni nyomon követése. Egyetlen olyan kérdés volt az én vizsgálatomban, ami a KSH kérdései között nem szerepelt. Ez az adó és adatszolgáltatásra vonatkozott, amit ma minden vállalkozásnak az ügyfélkapun keresztül kell megvalósítania, ez 70,7\%-ban volt jellemző az internet használatakor. Ez az adatsor nagyon hasonló a legfrissebb, rendelkezésemre álló KSH adatsorhoz, ami egy jó visszajelzés arra is, hogy a válaszadók őszinték voltak, és megbízhatóak a rendelkezésemre álló adatok.

3.2. A vállalkozás terveivel, fejlesztésével és a vezetéssel kapcsolatos kérdéskör eredményei

A kérdőív egyik fontos része a jövőre vonatkozó tervek megismerése, felmérése volt. A vizsgálatnak ebben a részében arra voltam kíváncsi, hogy milyen fejlesztési 
tervekkel rendelkeznek a megkérdezettek, hogyan kívánjak fejleszteni a digitális eszközökkel vállalkozásaikat, gazdasági lehetőségeiket. Természetesen az integrált rendszert nem használó vállalkozásoknál rákérdeztem arra, tervezik-e a vállalkozások az informatikai rendszerüket fejleszteni, esetleg integrált ügyviteli rendszerbe beruházni.

\section{2. ábra: Az integrált vállalatirányítási rendszerrel kapcsolatos tervek a szervezetekben}

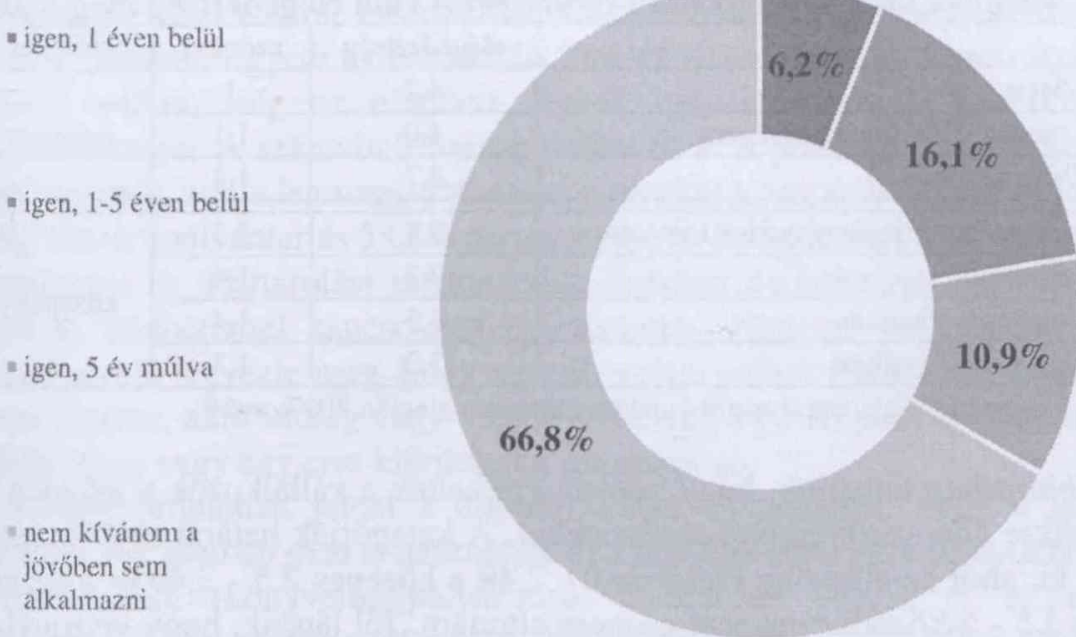

Forrás: Saját kutatás; $\mathrm{n}=181$

A 2. ábra mutatja, hogy 6,2 százalék válaszolta, hogy 1 éven belül van ilyen terve, 16,1 százalék pedig 5 éven belül szeretne informatikai fejlesztést. Valamivel több, mint $10 \%$ gondolta fontosnak, hogy 5 év múlva valamikor fog ebbe beruházni, de még így is maradt 66,8 százalék a válaszadók közül, aki egyáltalán nem tervezett informatikai fejlesztést. Rákérdeztem ennek okára. Egytől ötig terjedő skálán jelölhették be a vállalkozók, vezetők, milyen tényezők motiválják őket. Az egy jelentette, hogy legkevésbé fontos az érv, az öt pedig a leginkább fontos érv volt a döntéshozatal során. A válaszok között két eröteljesebb vélemény kapott hangot: 4,4 volt a „Kicsi a vállalkozás, nem lenne gazdaságos bevezetni” értéke, és „Így is tisztában vagyok a vállalkozással” $(4,1)$. A „magas költségü bevezetés” 3,6 és a „magas költséggel jár az üzemeltetés” 3,5 értékkel jelent meg, de a „müködési költség növekedése" is 3,6 számtani átlaggal szerepel a kiértékelésben. A legkevésbé fontos és lényeges érv a válaszlehetőségek között a belső kommunikáció romlása és az adatbiztonság esetében jelent meg. Az előbbi esetén az érték mindössze 1,8 volt, az utóbbi esetén, vagyis „túl sok adatot lehet kinyerni belölük, ezeket könnyebben megszerezheti a konkurencia" 2,1 erősséggel jelent meg a válaszok között. Ugyanakkor fontos érv volt még a felesleges adminisztráció, amit 3,4 pontra értékeltek a válaszadók. A nehézkesebb döntéshozatal és a dolgozók alacsony végzettsége miatti bevezetés nehézségei egyarán 2,4 értékkel jelentek meg. A nagy 
szervezeti ellenállás problémája 4,1 számtani átlaggal jelent meg, ami nagyon fontos szervezeti visszajelzés a vállalatirányítási rendszerekkel kapcsolatosan.

A kérdőív kérdései között voltak a már meglévő, a vállalkozók által használt információs rendszerekre vonatkozó kérdések, melyeket szintén 5 fokozatú Likert skálán helyeztem el. Itt jellemzően az első kérdésre, hogy a most használ szoftverrel/rendszerrel elégedett-e a vállalkozás vezetője 89,3 százalékban igennel válaszoltak a gazdálkodók.

\section{2. táblázat: Meglévő integrált ügyviteli rendszerrel való elégedettség megítélése}

\begin{tabular}{|l|c|c|c|}
\hline Válaszok & elégedettség & szórása & értékelés \\
\hline Felhasználóbarát & 4,2 & 1 & \\
\cline { 1 - 3 } Jól lefedi a gazdálkodási tevékenységem & 4,0 & 1,1 & \multirow{2}{*}{ magas } \\
\cline { 1 - 3 } Szoftver fejleszthetősége & 3,7 & 1,4 & \\
\hline \hline Alkalmas a gazdasági teljesítményének mérésére & 3,4 & 1,5 & \\
\cline { 1 - 3 } Javuló döntéshozatal & 3,3 & 1,4 & \multirow{2}{*}{ közepes } \\
\cline { 1 - 3 } Terv-tény elemzésre alkalmas & 3,3 & 1,4 & \\
\cline { 1 - 3 } Segíti a piacon való helytállást & 3,2 & 1,3 & \\
\hline
\end{tabular}

Forrás: Saját szerkesztés kutatási eredmény alapján 2017; n=89

A 2. táblázatban láthatjuk, hogy hogyan értékelték a vállalkozók a jelenleg is rendelkezésükre álló szoftvereket, rendszereket. A kategóriák határát saját magar alakítottam ki, ahol az alacsony esetében 0 - 2,49 a közepes 2,5 - 3,49 és a maga kategóriába 3,5 - 5 közötti értékeket csoportosítottam. Jól látszik, hogy viszonylą elégedettek a jelenlegi rendszerükkel a gazdálkodók, hiszen a legalacsonyabb érték válasz is a közepes kategóriába került. Az elégedettségre leginkább okot ado tényezők közé a felhasználóbarát tulajdonságot tették a válaszadók, ez 4,2-es számtani átlagot eredményezett. Emellett még 4,0 volt a ,jól lefedi a gazdálkodás tevékenységem". 3,7 átlaggal szerepelt a szoftver fejleszthetősége a szoftvernek és 3,4-es átlagot kapott az a tulajdonság, hogy alkalmas a gazdaság teljesítményének ? mérésére. A javuló döntéshozatal, a terv-tény elemzésre való alkalmasság, és a piacon való helytállás segítése egyaránt 3,3-es erősségű válaszokat adott.

A válaszok alapján kirajzolódik egy viszonylagos elégedettség a megkérdezettek körében a használatukban lévő informatikai rendszer iránt. Ez azért is lényeges, mer! tudjuk, hogy a legjobb marketing az elégedett vásárló, felhasználó. Így, az tapasztalataikra építve a fejlesztések is és a piaci lehetőségek egyaránt kiaknázhatók lennének.

Természetesen rákérdeztem arra, hogy mi lehet az oka annak, hogyha nem választaná a meglévő rendszerét a döntéshozó. A legtöbb válaszadó azt emelte kí hogy a most meglévő rendszer már inkább gátolja, mint segíti a gazdaságának fejlődését, emellett nehézkes, nem felhasználóbarát a szoftver és nem megfeleló karbantartás szerepelt, mint legnagyobb hátráltató tényező. Kiemelem még, hogy mind szóban, mind írásban túlnyomó részt dicsérték a vállalkozók a magyar szoftvereket, a magyar fejlesztéseket. Naprakésznek, könnyen elsajátíthatónak és rugalmasnak találták mind a rendszert, mind a fejlesztő és karbantartásért felelös 
informatikusokat, ami a használat terjesztése, terjedése szempontjából jelentős befolyásoló tényezőként jelenhet meg. Emellett kiemelték a viszonylag jó ár-érték arányt, ami szintén előny a külföldi szoftverekkel szemben.

A gazdálkodással kapcsolatban vezetett elektronikus nyilvántartásokra vonatkozó kérdéskörben több választ is meg lehetett jelölni. A megkérdezettek 54,4 százaléka jelezte, hogy vezet gazdálkodási naplót, táblatörzskönyvet pedig 34,9\% jelölte meg. A válaszadók fele permetezési naplót és 29,4\%-a állatállomány nyilvántartást is vezetett. A takarmány felhasználással kapcsolatban $20,6 \%$ jelezte a számítógép használatot, informatikai rendszerben állategészségügyi nyilvántartást $25,4 \%$ használt. Egyedi nyilvántartást $21 \%$ és állatállomány változás nyilvántartását $24,3 \%$ vallott, míg az elhullott állatok nyilvántartása 23,2\%-nál jelent meg elektronikusan. A számviteli nyilvántartást $64 \%$, a pénzügyi nyilvántartást $65,8 \%$ ban vezettek, ami a legmagasabb arány a megkérdezett nyilvántartások között. Volt még készletnyilvántartás $58,8 \%$ esetén és egyéb nyilvántartás $14 \%$-nál, mint például nemesítési és adattárolási információk, ingatlan nyilvántartás, bér és munkaügyi adatok, földbérlettel kapcsolatos nyilvántartás. Nagyon sok válaszadó az egyéb lehetőségnél jegyezte meg, hogy vezetik ugyan ezeket a nyilvántartásokat, de csak papír alapon, amit utólag vagy a könyvelö, vagy egy dolgozó digitalizál egy Excel táblázatban vagy egy erre kifejlesztett programban.

Nagy problémát jelent a digitalizálódás tekintetében, hogy a tulajdonosok, vezetők sok esetben nem is használják ki a digitális világ adta előnyöket: dolgozóik, megbízottjaik (könyvelő, pályázatíró, tanácsadó) végzik el az elektronikus adatszolgáltatási kötelezettség miatt adódó feladatokat, de nem ők maguk használják az IKT eszközöket, szoftvereket.

Fontosnak tartottam megkérdezni, hogy amennyiben foglalkozik szántóföldi növénytermesztéssel, rendelkezik-e GPS alapon vezérelt erő- és munkagépekkel, melynek eredményét a 3. ábrán mutatom be.

\section{3. ábra: A vállalkozás használ-e GPS alapon vezérelt mezőgazdasági eszközt a termelésben?}

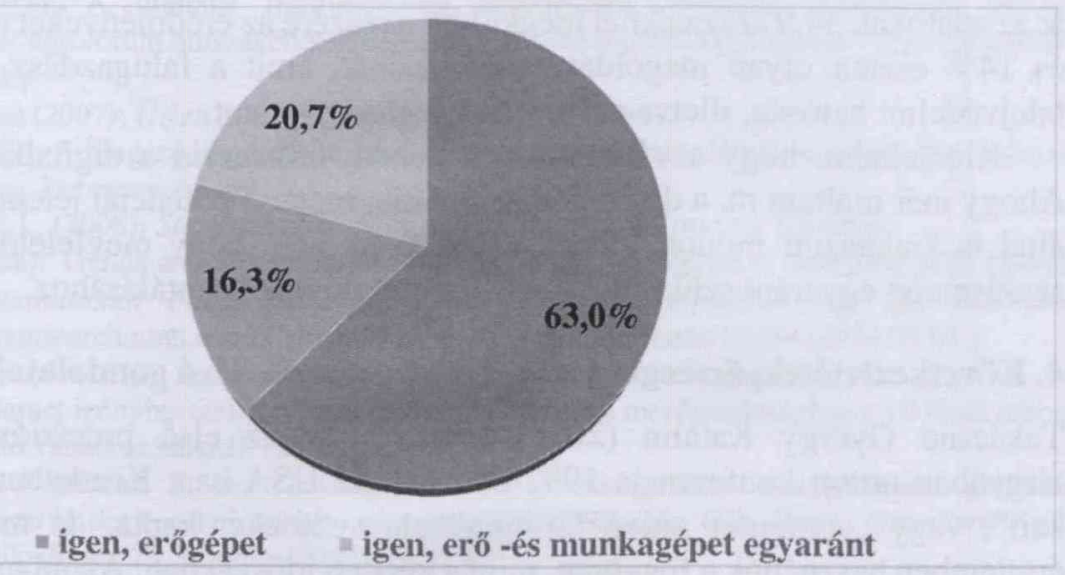

Forrás: Saját kutatás, 2017; n=255 
A 3. ábrán látható, hogy a válaszadók $63 \%$-a nemmel válaszolt, de 16,3 \% jelezte, hogy erőgépekkel és $20,7 \%$ pedig erő- és munkagépekkel is rendelkezett Összességében tehát $37 \%$ válaszolta, hogy használja a precíziós technikákat é technológiát a gazdálkodása során.

Feltettem azt a kérdést is, hogy szántóföldi növénytermesztés esetén használ precíziós mezőgazdasági rendszert. A válaszadók 16,4\%-a igennel válaszolt, neme pedig $65,8 \%$ mondott. Nem, de tervezi a bevezetését $17,8 \%$ esetében merült fel Végül megkérdeztem, hogy amennyiben használ precíziós mezőgazdasági rendszer hogyan jut hozzá az adatokhoz, eredményekhez. Ebben az esetben jóval kevesebb a adat, hiszen csak azok válaszoltak, akik ez előző kérdésben a precíziós rendsze használatát megjelölték.

A 4. ábra megmutatja, hogy a vállalkozások hogyan jutnak hozzá a GPS vezérel eszközök és a precíziós rendszer által biztosított adatokhoz.

\section{4. ábra: A vállalkozás precíziós adatokhoz való hozzájutása}

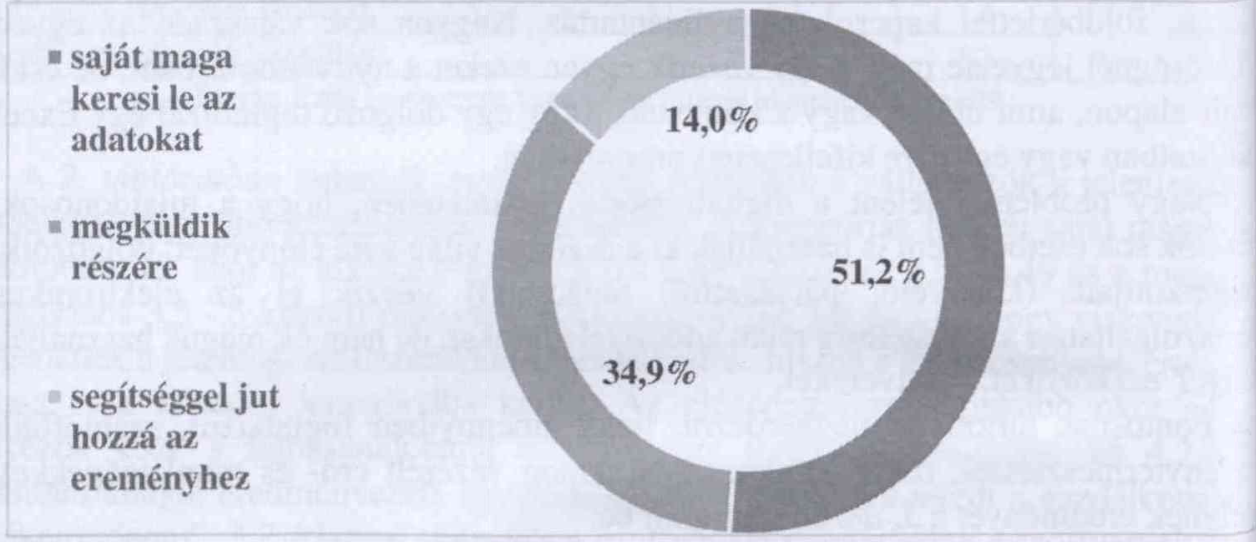

Forrás: Saját kutatás, 2017; n=39

A 4. ábrán láthatjuk, hogy a válaszadók $51,2 \%$-a jelezte, hogy saját maga keres le az adatokat, 34,9 százaléknál megküldik a részére az eredményeket és elemzéseke és $14 \%$ esetén olyan megoldást alkalmaznak, amit a falugazdász, a növény é talajvédelmi hatóság, illetve pályázatíró segítsége jelent.

Kiemelném, hogy a vállalkozások kezdik felismerni a digitalizáció előnyei Ahogy már utaltam rá, a dán példa is mutatja, mennyi potenciál jelentkezik a dáno által is kiaknázott módon. Ehhez azonban az kell, hogy megfelelő nyitottság é szakismeret egyaránt szükséges az IKT technológiák adaptálásához.

\section{Következtetések, összegzés, záró megjegyzések, záró gondolatok}

Takácsné György Katalin (2011) leírja, hogy az első precíziós gazdálkod tárgyában tartott konferencia 1992-ben volt az USA-ban. Kezdetben „farming b. soil”, vagy „computer aided farming” elnevezéseket kapta, de ma már tágab értelemben használják a fogalmat, mint a kezdeti időszakban. Azonban napjainkbart 25 évvel az első precíziós konferencia után, Varga (2016) kutatása azt mutatja, hog 
a mezőgazdaságban csak akkor használják az informatikát, ha muszáj: ha valamilyen szabályozás írja elő, esetleg nincs más megoldás. A jogszabályi kötelezettségen túl a digitális technológia, az ITC használata a mezőgazdasági termelők esetében csak nyomokban van jelen. Sok eszköz került be a gazdálkodásba, amelyben ott az informatika, szigetszerüen használják, de ezek nincsenek összekapcsolva és ma Magyarországon a termelésbe vont földterületnek mindössze 10 százaléka lefedett informatikával, ennyi helyen használják a precíziós mezőgazdaság valamilyen eszközét, leginkább az automatizálást. Pedig az informatikai eszközök alkalmazása révén a termelésben hektáronként 2,5 eurós, az üzemszinten bevezetett újdonságok révén pedig akár hektáronként 80 eurós megtakarítás lenne elérhető (Langenberg et.al, 2017). Ezek alapján kijelenthetjük, hogy nagy versenyhátrányt jelenthet az agárgazdaság számára az új technológiák adta lehetőségek kiaknázatlansága. Emellett a környezeti szempontok figyelembe vételével csökkenthetőek lennének a precíziós gazdálkodás, az integrált rendszerek használatával a negatív externális hatások, élelmiszertechnológiai és akár egészségügyi eredmények.

A vizsgálatom során a mezőgazdasági gazdálkodó szervezetekre és irányítóira fókuszáltam, melyek kutatása a többi szektorhoz viszonyítva mérsékeltebben jelenik meg a magyar kutatási területen. Jelentős változások zajlottak le informatikai területen, és ez nem kerülte ki a mezőgazdaságot sem. Eredményeim azt mutatják, hogy hazánkban van még fejlődési potenciál, ami egyrészről kedvező folyamatokat vetít elöre a hatékonyság és a termelékenység területén. Másrészről azt is megmutatják az adatok, hogy képzés és az agrárvállalkozók informatikai fejlesztése nélkül ezeknek a hiányosságoknak a fennmaradása hosszú távú versenyhátrányt fog jelenteni a magyar kis- és középvállalkozások számára.

\section{Irodalomjegyzék:}

Ackroyd, S., Huges, J.A. (1992): Data Collection in Context. Longman Publ. London and New York. Babbie, E. (2008): A társadalomtudományi kutatás gyakorlata. Balassi Kiadó, Budapest.

Brace, I. (2008): Questionnaire Design: How to Plan Structure and Write Survey Material for effect Market Research. Kogan Page, London \& Philadelphia, 2nd Edition.

Jóri J. I. (2017): A digitális mezőgazdaság fejlödésének története. Agrofórum Online. <http://www.agroforum.hu/szakcikkek/cema-digitalis-mezogazdasag-fejlodes enek-tortenete> (2017.06.03.)

Gábor A. és mtsai (2007): Üzleti informatika. Aula Kiadó, Budapest.

Györffy B. (1999): A biogazdálkodástól a precíziós mezőgazdaságig. III. Nemzetközi Tudományos Szeminárium, Debrecen, 63-69.

Hunyadi L., Vita L. (2008): Statisztika I-II. Aula Kiadó, Budapesti Corvinus Egyetem.

Jose, H. D. (2008): Trends and Opportunities in Agriculture An Executive Interview with Lowell Catlett. International Food and Agribusiness Management Review, 11 (4): 183-186. <http://ageconsearch.umn.edu/bitstream/53804/2/Catlett_For matted.pdf> (2014.03.01.)

Kárpáti L., Lehota, J. (2010): Agrármarketing. Szaktudás Kiadó Ház, Budapest.

KSH (2012): Internet igénybevételének százalékos megoszlása a mezögazdaságban a 10 fönél többet foglalkoztató vállalkozásoknál. (2013. 09.18.)

Langenberg, J., Nordhaus, F. B., Theuvsen, L. (2017): Navigations- und N-Sensor gestützte Anwendungen in der Landwirtschaft - eine Rentabilitätsanalyse. GIL, Bonn. <http://www.gilnet.de/Publikationen/29_97.pdf> (2017. 05. 31.) 
Popp, J. (2013): A mezőgazdaság jövője - a jövő mezőgazdasága. <http://agronaplo.hu/amezogazdasag-jovoje-a-jovo-mezogazdasaga/> (2015.12.20.)

Székelyné Raál, É. (2010): Kettős könyvvitelt vezető mezőgazdasági, vad-, erdőgazdálkodási és halászati szervezetek név- és címjegyzéke. AKI, Budapest. <https://www.aki.gov.hu/publikaciok/> (2011.05.26.)

Takácsné György, K. (2011): A precíziós növénytermelés közgazdasági összefüggései. Szaktudás Kiadó Ház, Budapest.

Tóth, T., Káposzta, J. (2013): Tervezési módszerek és eljárások a vidékfejlesztésben. Debreceni Egyetem Agrár- és Gazdálkodástudományok Centruma

Varga, P. (2016): Agrárdigitalizáció. <http://www.ivsz.hu> (2016.08.15.) 